\title{
Geographical controls on arsenic variability in groundwater of Upper Indus Basin, Punjab, Pakistan
}

\author{
A. Farooqi ${ }^{1}$, N. Mushtaq ${ }^{1}$, J.A. Khattak ${ }^{1}$, I. Hussain ${ }^{1} \&$ A. van Geen ${ }^{2}$ \\ ${ }^{1}$ Environmental Geochemistry Laboratory, Faculty of Biological Sciences, Department of Environmental Sciences, \\ Quaid-i-Azam University, Islamabad, Pakistan \\ ${ }^{2}$ Lamont Doherty Earth Observatory, Columbia University, Palisades, New York, USA
}

\begin{abstract}
Blanket testing was carried out in 179 villages in Upper Indus Basin of Punjab, Pakistan. Out of total 19551 wells tested, $79 \%$ were found to have arsenic levels within WHO prescribed limit of $10 \mu \mathrm{g} \mathrm{L}^{-1}$ while $11 \%$ had arsenic levels within National limit of $50 \mu \mathrm{g} \mathrm{L}^{-1}$. Ravi flood plain was found to be comparatively more contaminated than the rest of the study area. The prevailing redox conditions for arsenic release in Punjab is found to be mixed in nature, with conditions reducing enough for Fe oxide reduction but typically not enough for complete reduction of $\mathrm{SO}_{4}$.
\end{abstract}

\section{INTRODUCTION}

Naturally occurring high arsenic (As) concentrations in groundwater of flood plains of South East and South Asia are a threat to health of more than 100 million people living there (Postma et al., 2016). The source of As in groundwater is generally associated with sediments deposited by rivers originating in Himalayas. The general geochemical conditions or settings that lead to the mobilization of arsenic into groundwater include environments that are either reducing, arid or oxidizing with elevated $\mathrm{pH}$, geothermal or sulfide mineralization (Smedley \& Kinniburgh, 2002). It is a well-known fact that distribution of As in groundwater is highly variable spatially, and varies with the geology and soil properties of the area (Winkel et al., 2011). Occurrence of high As in groundwater has also been linked to recently abandoned river channels deposits (Sahu \& Saha, 2015), with concentrations changing as hydrogeology and water table also further influence mobilization of As (Postma et al., 2016). The groundwater and surface water of Indus River system is a key source of drinking water in Pakistan. A survey carried out jointly by local government and rural development department of Pakistan, public health engineering department, and United Nations International Children's Emergency Fund (UNICEF) indicated hot spots of As abundance in Indus alluvial basin of Pakistan specifically in the central and southern region of the country. (Rabbani et al., 2017) reported 13 million people to be at risk from drinking As contaminated groundwater from 27 districts of Sindh. Keeping these in mind, blanket testing was carried out in the Punjab region to identify areas contaminated with As and pinpoint the locations of safe wells using field kits. This transboundary research also focuses on the difference in geochemical settings in both India and Pakistan responsible for As release into groundwater.

\section{METHODS/EXPERIMENTAL}

\subsection{Geological background}

Blanket testing was carried out in Upper Indus Basin, Punjab region for the testing of As and selected redox parameters. The villages covered so far were selected using Google Earth imagery along the Pakistan part of the transects (Fig. 1). The aquifer system under doabs (area between two rivers) are underlain by unconsolidated alluvial sediments deposited by Indus river tributaries during Pleistocene-Recent age. The alluvial complex has an average thickness of more than 400 meters. The sediments consist of brownish-grey, fine to medium sand, silt and clay in varying proportions with quartz, muscovite, biotite, and chlorite making up the chief mineral constituents of the sediments. The shifting course of tributaries has imparted heterogeneous nature to alluvial complex resulting in little to no vertical or lateral continuity. But still the sediments on regional scale behave as homogeneous aquifer (Farooqi et al., 2014).

\subsection{Field sampling and analysis}

Between 2015 and 2017, more than 19551 wells have been tested for As by Arsenic Econo-Quick (TM) (EQ) kit in almost 14 districts of Punjab covering 175 villages across Punjab. $\mathrm{pH} / \mathrm{EC}$ and redox sensitive parameters $\mathrm{NO}_{3}, \mathrm{SO}_{4}$, and $\mathrm{Fe}$ were also measured on field using HANNA field kits. Total of 18533 tests were performed for all 5 parameters. $10 \%$ of samples 


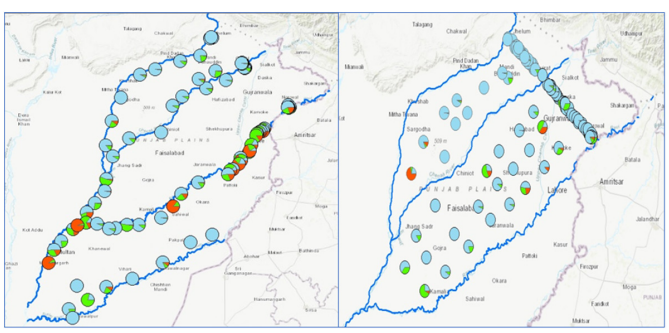

Figure 1. Distribution of arsenic in upper Indus Basin, Punjab, along Flood plains (left) and Doabs (right). The flood plain of Ravi is more affected by As contamination than Jhelum and Chenab, while northern part of the Rachna doab is comparatively more affected than Chaj doab.

were randomly collected for quality assurance for later laboratory analysis.

The sampling covered all the three-major flood plain areas of River Ravi, Chenab and Jhelum, and also covered both Rachna and Chaj Doabs.

\section{RESULTS AND DISCUSSION}

\subsection{Groundwater As distribution along Flood Plains}

Overall blanket testing results reveal that almost $79 \%$ of the wells tested had As concentration within WHO prescribed limit of $10 \mu \mathrm{g} \mathrm{L}^{-1}$ while $11 \%$ had concentrations within the National Environmental Quality Standards (NEQS) of $50 \mu \mathrm{g} \mathrm{L}^{-1}$. The testing covered major flood plains of the area and also the doabs (the area between two rivers). For better understanding of the arsenic distribution, the results are discussed separately for flood plains and doabs. $67 \%$ of the wells tested along flood plains of all three rivers (Ravi, Jhelum and Chenab) were found to be safe (As $<10 \mu \mathrm{g} \mathrm{L}^{-1}$ ) while $16 \%$ wells had As levels within the prescribed National Limit.

The comparison of proportion of wells unsafe regarding As (>WHO limit) concentrations showed Ravi flood plain to be more contaminated as compared to the Jhelum and Chenab Flood plains. $49 \%$ of the wells had As levels higher than $10 \mu \mathrm{g} \mathrm{L}^{-1} .29$ out of 34 villages tested along River Ravi had As $>50 \mathrm{ug} \mathrm{L}^{-1}$, more than that of national limit.

Along Chenab and Jhelum flood plains, only 13\% and $4 \%$ wells exceeded WHO limit, respectively.

The previously published data suggest the oxidative dissolution of As at higher $\mathrm{pH}$ to be the source of As release along Ravi river (Sultana et al., 2014).

\subsection{Arsenic in Chaj and Rachna Doabs}

Rachna Doab had comparatively higher proportion of unsafe wells (As $>10 \mu \mathrm{g} \mathrm{L}^{-1}$ ) than Chaj Doab (Fig. 1). $20 \%$ wells tested in Rachna and 2\% wells in Chaj had As levels above the prescribed WHO limit. Out of total 73 villages tested in both doabs, 10 villages had As
Table 1. Classification of redox parameters (percentage wise) on the basis of arsenic concentrations

\begin{tabular}{llll}
\hline Arsenic Classes & $\begin{array}{l}{ }^{*} \mathrm{Fe}>1 \\
\left(\mathrm{mg} \mathrm{L}^{-1}\right)\end{array}$ & $\begin{array}{l}* \mathrm{SO}_{4}>20 \\
\left(\mathrm{mg} \mathrm{L}^{-1}\right)\end{array}$ & $\begin{array}{l}* \mathrm{NO}_{3}-\mathrm{N}>10 \\
\left(\mathrm{mg} \mathrm{L}^{-1}\right)\end{array}$ \\
\hline As $\leq 10 \mu \mathrm{g} \mathrm{L}^{-1}$ & 24 & 81 & 91 \\
As $11-50 \mu \mathrm{g} \mathrm{L}^{-1}$ & 16 & 11 & 6 \\
As $>50 \mu \mathrm{g} \mathrm{L}^{-1}$ & 18 & 8 & 3 \\
\hline
\end{tabular}

*Detectable levels by Kits in $\mathrm{mg} \mathrm{L}^{-1}$

levels above $50 \mu \mathrm{g} \mathrm{L}^{-1}$. As seen from the Figure 1, the spatial distribution of As is highly variable and changes with the varying geological and topographic settings.

\subsection{Redox indicators}

Among the 11352 wells meeting the WHO prescribed limit of $10 \mu \mathrm{g} \mathrm{L}^{-1}$, only $24 \%$ samples had $\mathrm{Fe}>1 \mathrm{mg}$ $\mathrm{L}^{-1}$ and $76 \%$ samples having $\mathrm{SO}_{4}>20 \mathrm{mg} \mathrm{L}^{-1}$ detectable by kits. $\mathrm{NO}_{3}-\mathrm{N}>10 \mathrm{mg} \mathrm{L}^{-1}$ was detected in 1603 wells only using kits (Table 1). The overall redox parameter results indicate mixed conditions to be prevailing throughout study area with conditions often reducing enough for $\mathrm{Fe}$ oxide reduction but not enough for complete reduction of $\mathrm{SO}_{4}$.

\section{CONCLUSIONS}

The testing reveals wide variability in arsenic levels in groundwater with most of the samples meeting the WHO limit for drinking water in the Punjab region, Pakistan. Mixed redox settings were found to be responsible were elevated levels of As.

\section{ACKNOWLEDGEMENTS}

This project is funded by HEC-USAID under the Pak-USAID project.

\section{REFERENCES}

Postma, D., Larsen, F., Jakobsen, R., Sø, H.U. Kazmierczak, J.,Trang P.T.K., Lan, V.M., Viet, P.H., Hoan, H., Trung, D. \& Nhan, P.Q. 2016. On the spatial variation of arsenic in groundwater of the Red River floodplain, Vietnam. In: P. Bhattacharya, M. Vahter, J. Jarsjö, J. Kumpiene, A. Ahmad, C. Sparrenbom, G. Jacks, M.E. Donselaar, J. Bundschuh, \& R. Naidu (eds.) "Arsenic Research and Global Sustainability As 2016". CRC Press/Taylor and Francis (ISBN 978-1-138-02941-5), pp. 3-4.

Rabbani, U., Mahar, G., Siddique, A., \& Fatmi, Z. 2017. Risk assessment for arsenic-contaminated groundwater along River Indus in Pakistan.Environ. Geochem. Hlth. 39(1): 179-190.

Sahu, S. \& Saha, D. 2015. Role of shallow alluvial stratigraphy and Holocene geomorphology on groundwater arsenic contamination in the Middle Ganga plain, India. Environ. Earth. Sci. 73: 3523-3536. 
Smedley, P.L. \& Kinniburgh, D.G. 2002. A review of the source, behaviour and distribution of arsenic in natural waters. Appl. Geochem. 17(5): 517-568.

Sultana, J., Farooqi, A., \& Ali, U. 2014. Arsenic concentration variability, health risk assessment, and source identification using multivariate analysis in selected villages of public water system, Lahore, Pakistan. Environ. Mon Ass. 186(2): 1241-1251.
Winkel, L.H.E., Pham, T.K.T., Vi, M.L., Stengel, C., Amini, M., Nguyen, T.H., Viet, P.H. \& Berg, M. 2011. Arsenic pollution of groundwater in Vietnam exacerbated by deep aquifer exploitation for more than a century. Proc. Natl. Acad. Sci. U.S.A. 108: 1246-1251. 